\title{
Reversed Optical Rotation between Bispyridyl Diols and Their Dioxolanes Might Shed Explanation for the Evolution of Chirality
}

\section{Zuolin Zhu' ${ }^{1}$, Jonathan Zhu', Shanqing Sun², Tongxing Xie ${ }^{2}$}

${ }^{1}$ Sun Pharmaceuticals, Inc. Sorbonne Ct, San Diego, CA 92128
${ }^{2}$ Ningbo Yuchen Enviroclean Technology Co., Ltd, Zhejiang Province 315103, China

Abstract: Chiral bis(pyridyl)ethanediols and their corresponding dioxolanes have reversed optical rotation. The observed property of these chemicals could consummate the $\mathrm{CP}$-light destruction hypothesis for the appearance of pure chiral molecules for the evolution of chirality. Because bis(aryl)ethanediols are photolabile protecting groups, the diols and their corresponding dioxolanes might be potentially very small molecular switches.

Keywords: CP-light destruction hypothesis, chiroptical molecular switch, pyridyl compounds

\section{Introduction}

Chirality is one of the toughest scientific obstacles for evolution theory. One of the possible explanations would be enantiomer destruction by circularly polarized (CP) light, in which CP light is absorbed differently by left and right enantiomers, and photolysis (destruction by light) occurs only when light photons are absorbed. CP light was observed in a nebula ${ }^{1}$ and can be generated via natural optical active quartz ${ }^{2}$. Unfortunately, because both enantiomers absorb the same wavelength photons $\left[\alpha=n / \lambda\left(n_{L}-n_{R}\right) d\right]$, only $35.5 \%$ optical purity would have resulted after $99.99 \%$ destruction of the starting material. ${ }^{3}$ It is impossible to produce the necessary $100 \%$ homochirality required for life. This hypothesis needs additional modification or supplement.

Molecular switches are present in practically every important biological process ${ }^{4}$. The design of molecular switches is a major challenge in contemporary science. Chiroptical molecular switches is an important subgroup where switching takes place between enantiomeric pairs ${ }^{5}$. During our investigation of oxygen activation at ambient temperature for air purification, we discovered that xanthones-like organic chemicals can activate dioxygen for the oxidation of benzene and toluene (XANthones autoxidation of organics). ${ }^{6}$ Thus, many different compounds with similar structures are designed and synthesized, in hopes of identifying a much more powerful catalytic system.

\section{Materials and Methods}

(2R,3R)-2,3-butanediol

and

(1R,2R)-1,2-

diphenylethane-1,2-diol were used without purification. The HPLC analysis was carried out using HPLC chromatograph, chiral column $150 \mathrm{mmX} 4.6 \mathrm{~mm}$. The mobile phase is hexane/ethanol $=95: 5$, the flow rate is $1 \mathrm{ml} / \mathrm{min}$, and detection is at $260 \mathrm{~nm}$. Preparation of chiral diols was performed on the preparation HPLC, equipped with an auto-sampler. The chiral column is $250 \times 20 \mathrm{~mm}$ ID, the mobile phase is hexane/ethanol=95:5, and the flow rate is $18 \mathrm{ml} / \mathrm{min}$. Optical rotation was measured using a automatic polarimeter. MS, NMR and elemental analysis were outsourced.

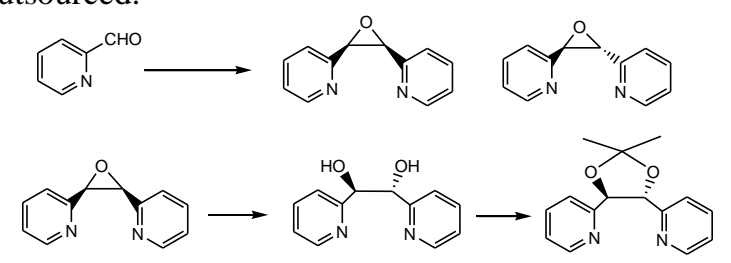

Figure 1. Preparation Pathway of chiral 1,3-dioxolane

Preparation of cis-epoxide ${ }^{9}$ : Under a nitrogen atmosphere, 20 grams of pyridinecarboxaldehyde was added to a dried flask that was cooled with an ice-water bath. The solution composed of 27 grams of $\left(\mathrm{Et}_{2} \mathrm{~N}\right)_{3} \mathrm{P}$ in benzene and hexane (20ml, 1:1 volume/volume) was added dropwise in order to maintain the reaction temperature below $5 \square \mathrm{C}$. The ice-water bath was removed after completing the addition of $\left(\mathrm{Et}_{2} \mathrm{~N}\right)_{3} \mathrm{P}$. The

This article is published under the terms of the Creative Commons Attribution License 4.0 Author(s) retain the copyright of this article. Publication rights with Alkhaer Publications.

Published at: http://www.ijsciences.com/pub/issue/2016-07/

DOI: 10.18483/ijSci.1051; Online ISSN: 2305-3925; Print ISSN: 2410-4477 
temperature of the reaction solution was slowly raised to room temperature. Stirring continued overnight at room temperature. $5 \mathrm{ml}$ water was added to the reaction mixture and stirred for about 30 minutes. The reaction mixture was poured into $200 \mathrm{ml}$ water, then extracted with hexane $(3 \times 200 \mathrm{ml})$ three times, followed by extraction with dichloromethane twice $(2 \times 200 \mathrm{ml})$. The combined organic extracts were concentrated, and water was removed by azeotropic distillations with toluene 4 times $(4 \times 150 \mathrm{ml})$. The cis-epoxide was obtained using silica gel eluted with acetonedichloromethane.

\section{Cis-2,3-di(pyridine-2-yl)oxirane:}

${ }^{1} \mathrm{HNMR}\left(\mathrm{CDCl}_{3}\right): \delta 4.58(\mathrm{~s}, 2 \mathrm{H}), 7.06-7.10(\mathrm{~m}, 2 \mathrm{H}), 7.20-$ 7.27(m,2H), 7.46-7.57(m,2H), 8.40-8.50(m,2H). ${ }^{13} \mathrm{CNMR}\left(\mathrm{CDCl}_{3}\right)$ 859.5(d), 121.4(d), 122.5(d), 135.7(d), 149.1(d), 154.0(s). MS Calcd. for $\left[\mathrm{C}_{12} \mathrm{H}_{10} \mathrm{~N}_{2} \mathrm{O}\right]$ 198.1, found $199.0\left(\left[\mathrm{M}^{+}+\mathrm{H}\right], \mathrm{LC} / \mathrm{MS} \mathrm{ESI}\right)$

Cis-2,3-di(pyridine-3-yl)oxirane:

${ }^{1} \mathrm{HNMR}\left(\mathrm{CDCl}_{3}\right)$ : $84.47(\mathrm{~s}, 2 \mathrm{H}), 7.07-7.20(\mathrm{~m}, 2 \mathrm{H}), 7.38-$ 7.51 $(\mathrm{m}, 2 \mathrm{H}), \quad 8.38-8.45(\mathrm{~m}, 2 \mathrm{H}), \quad 8.45-8.57(\mathrm{~m}, 2 \mathrm{H})$. ${ }^{13} \mathrm{CNMR}\left(\mathrm{CDCl}_{3}\right): \delta 57.4(\mathrm{~d}), 122.8(\mathrm{~d}), 129.4(\mathrm{~s}), 134.2(\mathrm{~d})$, 148.0(d), 149.2(s). MS Calcd. for $\left[\mathrm{C}_{12} \mathrm{H}_{10} \mathrm{~N}_{2} \mathrm{O}\right]$ 198.1, found $199.2\left(\left[\mathrm{M}^{+}+\mathrm{H}\right], \mathrm{LC} / \mathrm{MS} \mathrm{ESI}\right)$

Cis-2,3-di(pyridine-4-yl)oxirane:

${ }^{1} \mathrm{HNMR}\left(\mathrm{CDCl}_{3}\right): \delta 4.40(\mathrm{~s}, 2 \mathrm{H}), \quad 6.90-7.10(\mathrm{~m}, 4 \mathrm{H}), \quad 8.30-$ 8.50(m,4H). $\quad{ }^{13} \mathrm{CNMR}\left(\mathrm{CDCl}_{3}\right): \delta 58.3(\mathrm{~d}), \quad 121.5(\mathrm{~d})$, 142.4(s), 149.5(d). MS Calcd. for $\left[\mathrm{C}_{12} \mathrm{H}_{10} \mathrm{~N}_{2} \mathrm{O}\right]$ 198.1, found $199.2\left(\left[\mathrm{M}^{+}+\mathrm{H}\right], \mathrm{LC} / \mathrm{MS}\right.$ ESI $)$

Preparation of chiral diols ${ }^{10,11}: 20$ grams of cisepoxide in dioxane was added slowly into $60 \mathrm{ml}$ aqueous solution of sodium hydroxide $(10 \mathrm{~g})$, with an internal temperature constantly maintained below $60 \square$ C. After two hours of stirring, the mixture was neutralized with concentrated hydrochloric acid to $\mathrm{pH}=9$. Rotavap removed most of the solvents, and then the formed trans-diol was extracted with ethyl acetate $(3 \times 100 \mathrm{ml})$. The ethyl acetate extract was washed with brine $(70 \mathrm{ml})$, and dried over anhydrous sodium sulfate. The solvent was evaporated under vacuum and the product was recrystallized from ethyl acetate. (R,R)isomer of the diol was separated using high performance liquid chromatography preparation. Elution of the desired diol is behind the $(\mathrm{S}, \mathrm{S})$-isomer.

(1R,2R)-1,2-di(pyridin-2-yl)ethane-1,2-diol:

${ }^{1} \mathrm{HNMR}\left(\mathrm{CD}_{3} \mathrm{OD}\right): \quad \delta 5.10(\mathrm{~s}, 2 \mathrm{H}), \quad 7.36(\mathrm{~m}, 2 \mathrm{H})$, 7.42(m,2H), 7.82(m,2H), 8.50(m,2H). ${ }^{13} \mathrm{CNMR}\left(\mathrm{CD}_{3} \mathrm{OD}\right): \quad \delta \quad 78.4(\mathrm{~d}), \quad 123.9(\mathrm{~d}), \quad 124.2(\mathrm{~d})$, 138.2(d), 149.1(d), 161.9(s). MS Calcd. for $\left[\mathrm{C}_{12} \mathrm{H}_{12} \mathrm{~N}_{2} \mathrm{O}_{2}\right] 216.1$, found $217.1\left(\left[\mathrm{M}^{+}+\mathrm{H}\right], \mathrm{LC} / \mathrm{MS}\right.$ ESI). $[\square]^{20}{ }_{\mathrm{D}}=-52^{\circ}(\mathrm{c}=1.0, \mathrm{EtOH})$

(1R,2R)-1,2-di(pyridin-3-yl)ethane-1,2-diol:

${ }^{1} \mathrm{HNMR}\left(\mathrm{CD}_{3} \mathrm{OD}\right): \quad$ $\quad$ 55.00(s,2H), $\quad$ 7.42(m,2H),
7.78(m,2H), 8.39-8.51(m,4H). ${ }^{13} \mathrm{CNMR}\left(\mathrm{CD}_{3} \mathrm{OD}\right):$ 878.2(d), 126.0(d), 138.4(d), 139.7(s), 150.5(d, two carbon overlapped). MS Calcd. for $\left[\mathrm{C}_{12} \mathrm{H}_{12} \mathrm{~N}_{2} \mathrm{O}_{2}\right] 216.1$, found $217.2\left(\left[\mathrm{M}^{+}+\mathrm{H}\right]\right.$, LC/MS ESI). $[\square]^{20}{ }_{\mathrm{D}}=-28^{\circ}(\mathrm{c}=1.0$, $\mathrm{EtOH})$

(1R,2R)-1,2-di(pyridin-4-yl)ethane-1,2-diol:

${ }^{1} \mathrm{HNMR}\left(\mathrm{CD}_{3} \mathrm{OD}\right): \quad \delta 4.90(\mathrm{~s}, 2 \mathrm{H}), \quad 7.35(\mathrm{~m}, 4 \mathrm{H})$, 8.42(m,4H). ${ }^{13} \mathrm{CNMR}\left(\mathrm{CD}_{3} \mathrm{OD}\right): \delta 77.2(\mathrm{~d}), 124.1(\mathrm{~d})$, 149.1(d), 153.4(s). MS Calcd. for $\left[\mathrm{C}_{12} \mathrm{H}_{12} \mathrm{~N}_{2} \mathrm{O}_{2}\right]$ 216.1, found $217.1\left(\left[\mathrm{M}^{+}+\mathrm{H}\right], \mathrm{LC} / \mathrm{MS} \mathrm{ESI}\right) .[\square]^{20} \mathrm{D}=-22^{\circ}$ $(\mathrm{c}=1.0, \mathrm{EtOH})$

Preparation of 1,3-dioxolane , $^{8,12-15}$ : $1 \mathrm{~g}$ of strong acidic ionic exchange resin (D001) was added to the solution of $4.3 \mathrm{~g}$ of diol in $50 \mathrm{ml}$ of acetone and $50 \mathrm{ml}$ of 2,2dimethoxypropane. The mixture was refluxed for 2 hours, cooled to room temperature, and was then followed by filtering out the resin. The solvents were removed under vacuum, and residue was recrystallized from ethyl acetate.

(4R,5R)-2,2-dimethyl-4,5-bis(2-pyridyl)-1,3dioxolane: HPLC Purity $>99 \%$, optical purity $>99 \%$ ee. $[\square]^{20}{ }_{\mathrm{D}}=+66^{\circ}(\mathrm{c}=1.0, \quad \mathrm{EtOH}) . \quad{ }^{1} \mathrm{HNMR}\left(\mathrm{CD}_{3} \mathrm{OD}\right)$ : $\delta 1.65(\mathrm{~s}, 6 \mathrm{H}), \quad 5.25(\mathrm{~s}, 2 \mathrm{H}), \quad 7.21(\mathrm{t}, 2 \mathrm{H}), \quad 7.53(\mathrm{~d}, 2 \mathrm{H})$, 7.69(t,2H), 8.53(d,2H); ${ }^{13} \mathrm{CNMR}\left(\mathrm{CD}_{3} \mathrm{OD}\right): \delta 27.1(2 \mathrm{C})$, 84.3(2C), 110.6, 121.6, 123.0, 136.6, 149.5, 157.8; Elemental Anal. Calcd for $\mathrm{C}_{15} \mathrm{H}_{16} \mathrm{~N}_{2} \mathrm{O}_{2}$ : C70.29, H6.29, N10.93; Found C70.11, H6.32, N10.72

(4R,5R)-2,2-dimethyl-4,5-bis(3-pyridyl)-1,3dioxolane: HPLC Purity $>99 \%$, optical purity $>99 \%$ ee. $[\square]^{20}{ }_{\mathrm{D}}=+40^{\circ}(\mathrm{c}=1.0, \quad \mathrm{EtOH}) . \quad{ }^{1} \mathrm{HNMR}\left(\mathrm{CD}_{3} \mathrm{OD}\right)$ : $\delta 1.66(\mathrm{~s}, 6 \mathrm{H}), \quad 5.25(\mathrm{~s}, 2 \mathrm{H}), \quad 7.08-7.22(\mathrm{~m}, 2 \mathrm{H}), \quad 7.40-$ 7.53(m, $2 \mathrm{H}), \quad 8.2-8.4(\mathrm{~m}, 2 \mathrm{H}), \quad 8.5-8.6(\mathrm{~m}, 2 \mathrm{H})$; ${ }^{13} \mathrm{CNMR}\left(\mathrm{CD}_{3} \mathrm{OD}\right): \delta 26.8(2 \mathrm{C}), 84.2(2 \mathrm{C}), 110.5,122.8$, 129.5, 134.2, 148.1, 149.2; Elemental Anal. Calcd for $\mathrm{C}_{15} \mathrm{H}_{16} \mathrm{~N}_{2} \mathrm{O}_{2}$ : C70.29, H6.29, N10.93; Found C70.38, H6.17, N10.75

(4R,5R)-2,2-dimethyl-4,5-bis(4-pyridyl)-1,3dioxolane: HPLC Purity $>99 \%$, optical purity $>99 \%$ ee. $[\square]^{20}{ }_{\mathrm{D}}=+38^{\circ}(\mathrm{c}=1.0, \quad \mathrm{EtOH}) . \quad{ }^{1} \mathrm{HNMR}\left(\mathrm{CD}_{3} \mathrm{OD}\right)$ : $\delta 1.67(\mathrm{~s}, 6 \mathrm{H}), \quad 5.23(\mathrm{~s}, 2 \mathrm{H}), \quad 6.92-7.12(\mathrm{~m}, 4 \mathrm{H}), \quad 8.3-$ $8.5(\mathrm{~m}, 4 \mathrm{H}) ;{ }^{13} \mathrm{CNMR}\left(\mathrm{CD}_{3} \mathrm{OD}\right): \delta 26.8(2 \mathrm{C}), 84.6(2 \mathrm{C})$, 110.6, 121.6, 143.3, 149.5; Elemental Anal. Calcd for $\mathrm{C}_{15} \mathrm{H}_{16} \mathrm{~N}_{2} \mathrm{O}_{2}$ : C70.29, H6.29, N10.93; Found C70.26, H6.23, N10.69

\section{(4R,5R)-2,2-dimethyl-4,5-diphenyl-1,3-}

dioxolane:Chromatographic purification on silica gel eluted with petroleum ether/diethyl ether(9:1). $[\square]^{20}{ }_{\mathrm{D}}=+49^{\circ}(\mathrm{c}=1.0, \quad \mathrm{EtOH}) . \quad{ }^{1} \mathrm{HNMR}\left(\mathrm{CDCl}_{3}\right)$ : $\delta 1.69(\mathrm{~s}, 6 \mathrm{H}), \quad 4.75(\mathrm{~s}, 2 \mathrm{H}), \quad 7.28-7.50(\mathrm{~m}, 10 \mathrm{H})$. ${ }^{13} \mathrm{CNMR}\left(\mathrm{CDCl}_{3}\right) \quad \delta 27.2(2 \mathrm{C}), 85.5(2 \mathrm{C}), 109.3,126.6$, $128.2,128.4,128.5,130.3,133.7,136.8$. Elemental 
Anal. Calcd for $\mathrm{C}_{17} \mathrm{H}_{18} \mathrm{O}_{2}$ : C80.28, H7.13; Found C80.11, H7.23

\section{Results and Discussion}

Chiral bis(pyridyl)ethanediols are found to be able to change their optical rotation through a simple one-step chemical reaction shown in Figure 2. According to literature, dioxolane can be prepared by the reaction between diol and 2,2-dimethoxyprane in the presence of acid catalyst ${ }^{16}$, and bis(aryl)ethanediols are photolabile protecting groups ${ }^{17}$. The property of these chemicals makes them not only potentially very small molecular switches, but also might shed light on the evolution of Chirality.
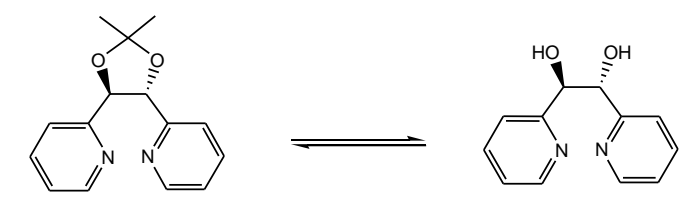

$[\sigma]^{20}{ }_{\mathrm{D}}=+66^{\circ}[\mathrm{c}=1.0, \mathrm{EtOH}]$

$[\sigma]^{20}{ }_{D}=-52^{\circ}[\mathrm{c}=1.0, \mathrm{EtOH}]$

(4R, 5R)-2,2-dimethyl-

4,5-bis(2-pyridyl)-1,3-dioxolane

(1R, 2R)-1,2-bis(2-pyridyl) ethane-1,2-diol

gure 2. The optical rotation changes from $+66^{\circ}$ degrees to $-52^{\circ}$ degrees without configuration change.

Amino acids and DNA bases are the most important building blocks of life, and they are all nitrogen contained compounds. This discovery might show that the correct enantiomer may survive $\mathrm{CP}$ light destruction through forming some kind of oligomer or complex that will change its photon absorption to different wavelengths in order to avoid the destruction by $\mathrm{CP}$ light, as shown by Figure $\mathbf{3}$.

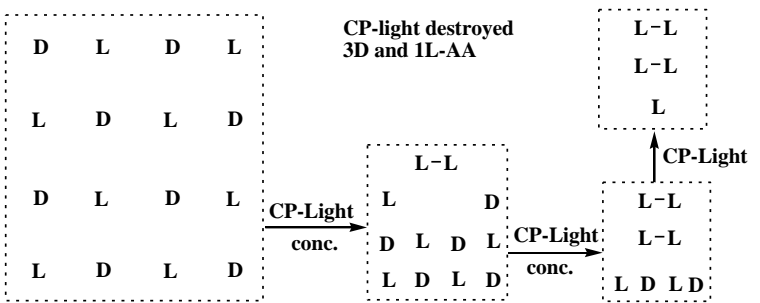

Figure 3. CP-light radiation destroys three D-AA and one L-AA in the same time. Meanwhile, the primordial soup begins to concentrate, Excess L-AA forms oligomers which absorbs at different wavelength (cannot be destroyed).

Two synthetic methods were used for the preparation of (4R, 5R)-2,2-dimethyl-4,5-bis(2-pyridyl)-1,3-dioxolane. The pure chiral product was prepared from $(4 \mathrm{R}, 5 \mathrm{R})$ 2,2-dimethyl-(1,3)-dioxolane-4,5-dicarbonitrile and ethyne according to the literature ${ }^{7}$. The dl-isomers were prepared using 2-pyridyl-aldehyde as a starting material and bis-(2-pyridyl)-epoxide as an intermediate. The cis-epoxide was isolated using a silica gel column eluted by acetone-methylene chloride. Then the

synthesized cis-epoxide was hydrolyzed using aqueous sodium hydroxide solution to yield trans-diol products. $(\mathrm{R}, \mathrm{R})$-isomers were obtained using the semi-prep Chiralcel OD-H column. The corresponding (R,R)dioxolanes were made using the reaction of the diols with 2,2-dimethoxypropane.

All organic compounds are prepared according to literature ${ }^{8-14}$. The results show that all pyridyl compounds have a reversed optical rotation between the diol and the corresponding dioxolane (Figure 2). In order to show that aromatic diols with the same chemical structure will all demonstrate this phenomena of reversing optical rotations, we choose (1R,2R)-1,2diphenylethane-1,2-diol as the corresponding analog. Unfortunately, unlike pyridyls chemicals, phenylderivative does not have this kind of property, as listed in Table $\mathbf{1}$ above.

Table 1. Optical Rotation of Diols and the Corresponding 1,3-Dioxolanes

\begin{tabular}{|c|c|c|}
\hline $\begin{array}{l}\text { Substituted } \\
\text { Group R=- }\end{array}$ & +66 & -52 \\
\hline 2-Pyridyl- & +40 & -28 \\
\hline 3-Pyridyl- & +38 & -22 \\
\hline 4-Pyridyl- & +49 & +92 \\
\hline Phenyl- & +40 \\
\hline
\end{tabular}

Pyridyl chemicals show the change of optical rotation. Phenyl chemical does not change

The observed property of these chemicals with nitrogen consummates the $\mathrm{CP}$-light destruction hypothesis for the appearance of pure chiral molecules for evolution, because amino acids are the key building block for life on earth. This observed result can explain the survival of the correct enantiomer of amino acids.

Amino acids have both carboxylic and amino groups. These groups tend to bind with each other to form some kind of oligomer. Carbon-carbon bond of oligomers cannot rotate freely, similar to that of 1,3dioxolane of pyridyl compounds. At the beginning of the amino acid formation, their concentrations are very low, and equal amounts of D and L-enantiomers are formed in pairs. The carbon-carbon bond of amino acids can rotate freely, similar to that of the diols of the pyridyl compounds. When the $\mathrm{CP}$ light began to destroy more "wrong" enantiomers and less "right" enantiomers, the "right" enantiomers are in excess. When the primordial soup continued to concentrate, the "right" enantiomers formed oligomers that not only reversed its optical rotation but also to a different wavelength, thus the "right" enantiomer could survive, 
$100 \%$ homochirality is obtained for life.

Conclusion

Bis(pyridyl)ethanediols and their corresponding 2,2dimethyl-(1,3)-dioxolane derivatives have reserved optical rotation. These compounds are potentially very small molecular switches. The property of optical rotation may be able to explain the evolution of chirality.

\section{REFERENCES AND NOTES}

1. Bailey J, Chrysostomou A, Hough JH, Gledhill TM, McCall A Clark S, Ménard F, Tamura M. Circular polarization in starformation regions: implications for biomolecular homochirality, Science 1998; 281:672-674.

2. Laurence D. Barron. Molecular Light Scattering and Optical Activity, London: Cambridge University Press; 2006.

3. Belavoine G, Moradpour A, Kagan HB, Preparation of Chiral Compounds with High Optical Purity by Irradiation with Circularly Polarised Light. J Am Chem Soc 1974; 96: 51525158.

4. Schliwa, M. Molecular Motors, Wiley-VCH; 2003.

5. Mammana A, Carroll GT, Feringa BT. Circular Dichroism of Dynamic Systems: Switching Molecular and Supramolecular Chirality, John Wiley and Sons; 2012.

6. Zhu Z, Zhu J, Catalytic oxygen atom transfer from lignin to cellulose and hemicellulose and its importance in biorefining, Fuel 2015; 148:226-230.

7. Saha S, Flood AH, Stoddart JF, Impellizzeri S, Silvi S, Venturi M, Credi A, A Redox-Driven Multicomponent Molecular Shuttle, J Am Chem Soc 2007; 129:12159-12171.

8. Hernandez JV, Kay ER, Leigh DA. A reversible synthetic rotary molecular motor, Science 2004; 306:1532-1537.

9. Heller B, Sundermann B, Fisher C, You J, Chen W, Drexler HJ Knochel P, Bonrath W, Gutnov A. Facile and Racemization-
Free Conversion of Chiral Nitriles into Pyridine Derivatives, $J$ Org Chem 2003; 68:9221-9225.

10. Liu X, Verkade JG. P( $\left(\mathrm{MeNCH}_{2} \mathrm{CH}_{2}\right)_{3} \mathrm{~N}$ : A Highly Selective Reagent for Synthesizing trans-Epoxides from Aryl Aldehydes, J Org Chem 2000; 65:4560-4564.

11. Cabras MA, Chelucci G, Giacomelli G, Soccolini F. Optically active pyridine derivatives as catalysts in the enantioselective addition of diethylzinc to benzaldehyde, Gazzetta Chimica Italiana 1994; 124:23-25.

12. Imuta, M.; Ziffer, H. Preparation and absolute stereochemistry of isomeric pyridylethanols and threo-di(2-pyridyl)ethanediol, J Org Chem 1978; 43:3530-3532.

13. Chelucci, G.; Falorni, M.; Giacomelli, G. Chiral ligands containing heteroatoms, 6. 1-(2-Pyridylmethyl)pyrrolidine in the chiral catalysis of addition of diethylzinc to benzaldehyde, Tetrahrdron: Asymmetry 1990; 1:843-849.

14. Stanbury, D. M.; Gaswick, D.; Brown, G. M.; Taube, H Autoxidation of binuclear ruthenium(II) ammines, Inorg Chem 1983; 22:1975-1982.

15. Solladie-Cavallo A, Choucair E, Balaz M, Lupattelli P, Bonini C, Blasio ND. A Mild Stereo- and Enantiospecific Conversion of 2,3-Diaryl-Substituted Oxiranes into 2,2-Dimethyl-1,3Dioxolanes by an Acetone/Amberlyst 15 System, Eur J Org Chem 2006;2006(13):3007-3011.

16. Carey FA, Sundberg RJ. Advanced Organic Chemistry, Part B: Reaction and Synthesis, Springer-Verlag US; 2007.

17. Blanc A, Bochet CG. Bis(o-nitrophenyl)ethanediol: A Practical Photolabile Protecting Group for Ketones and Aldehydes, J Org Chem 2003; 68 (3):1138-1141.

Graphical Abstract

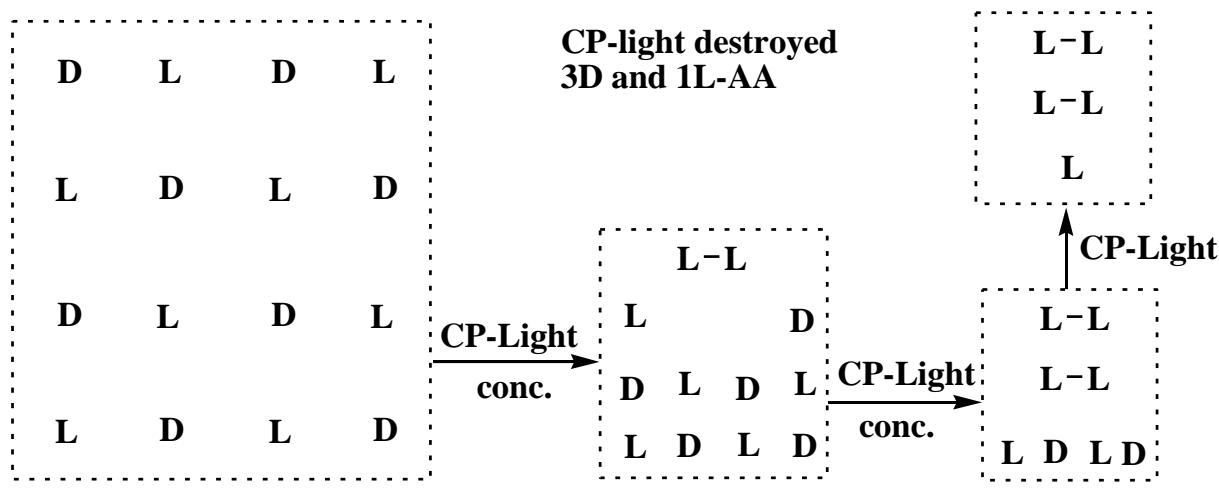

$\mathrm{CP}$-light radiation destroys three D-AA and one L-AA in the same time. Meanwhile, the primordial soup begins to concentrate, excess L-AA forms oligomers which absorb at different wavelength (cannot be destroyed). 